
of Engineers $s_{\circledast}$

Engineer Research and

Development Center

\title{
3-D Scanning of Headstones at the U.S. Naval Plot, Mount Moriah Cemetery, Philadelphia, PA
}

Carey L. Baxter, Andrew M. Hamblin, and Susan I. Enscore

November 2017

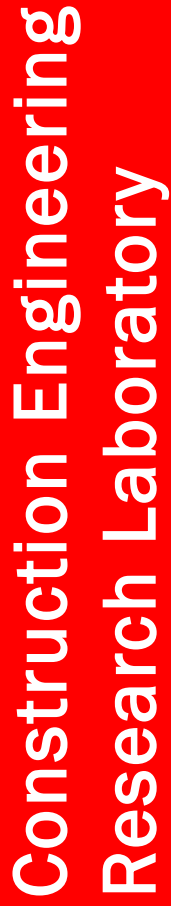

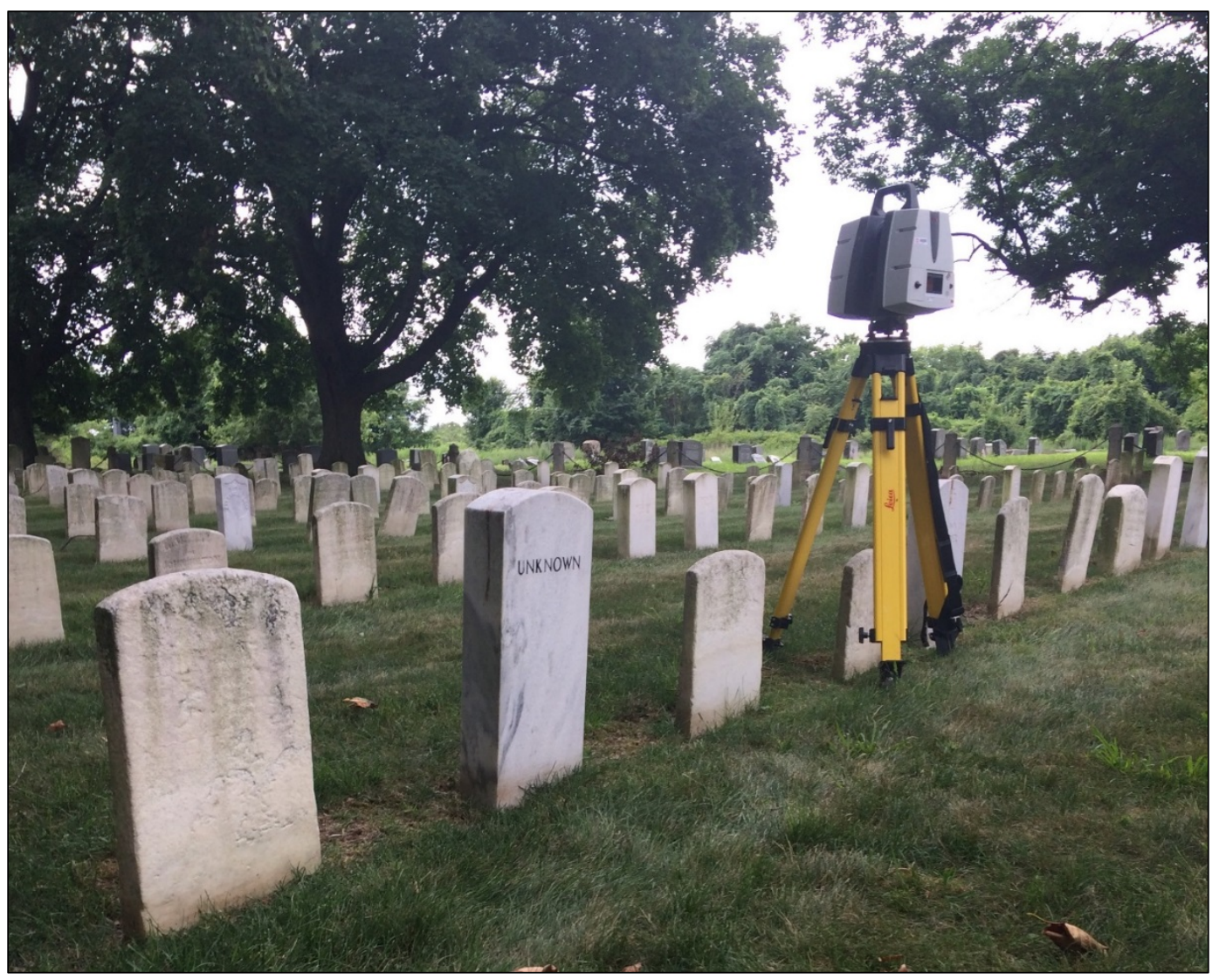


The U.S. Army Engineer Research and Development Center (ERDC) solves the nation's toughest engineering and environmental challenges. ERDC develops innovative solutions in civil and military engineering, geospatial sciences, water resources, and environmental sciences for the Army, the Department of Defense, civilian agencies, and our nation's public good. Find out more at www.erdc.usace.army.mil.

To search for other technical reports published by ERDC, visit the ERDC online library at http://acwc.sdp.sirsi.net/client/default. 


\section{3-D Scanning of Headstones at the U.S. Naval Plot, Mount Moriah Cemetery, Philadelphia, PA}

Carey L. Baxter, Andrew M. Hamblin, and Susan I. Enscore

Construction Engineering Research Laboratory

U.S. Army Engineer Research and Development Center

2902 Newmark Drive

Champaign, IL 61822

Final Report

Approved for public release; distribution is unlimited.

Prepared for National Cemetery Administration

Washington, DC 20420

Under Project 467132, “3-D Scanning of Military Grave Markers at Mount Moriah Cemetery, Philadelphia PA" 


\section{Abstract}

The site of this study was Mount Moriah Cemetery, a historic cemetery in Philadelphia, PA. Several historical types of headstones dating from the middle of the 19th through the middle of the 2oth century were imaged with a Leica P40 laser scanner. The objective of this study was to use three-dimensional laser imagining to collect specifics of lettering fonts and placement for appropriate replication. At least three scanning stations were used for each headstone. A total of 67 scans were taken. Lettering was traced and provided in digital format. These letters were further processed in AutoCAD. Three-dimensional imaging provided useful information that can be modeled and replicated for reconstruction of headstones.

DISCLAIMER: The contents of this report are not to be used for advertising, publication, or promotional purposes. Citation of trade names does not constitute an official endorsement or approval of the use of such commercial products. All product names and trademarks cited are the property of their respective owners. The findings of this report are not to be construed as an official Department of the Army position unless so designated by other authorized documents. 


\section{Contents}

Abstract.......................................................................................................................... if

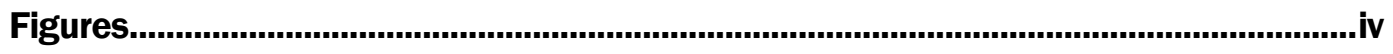

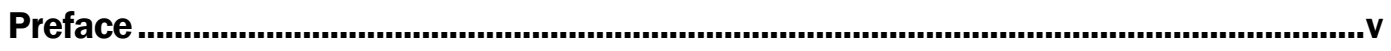

Unit Conversion Factors............................................................................................vi

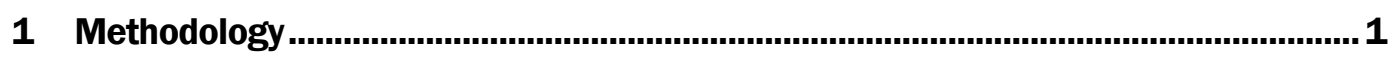

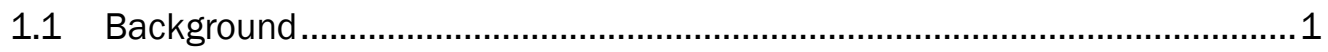

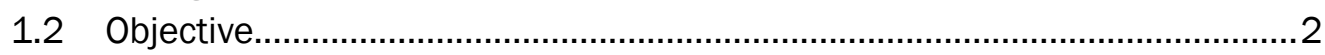

1.3 Researchers ................................................................................... 2

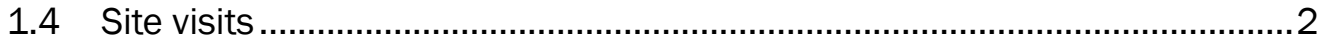

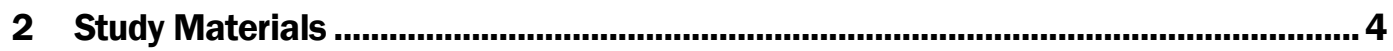

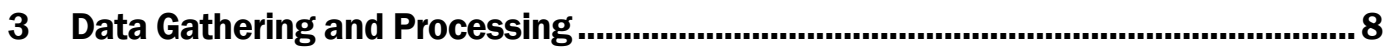

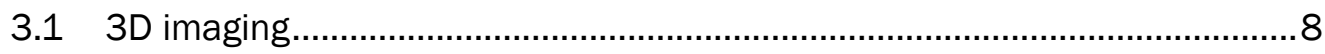

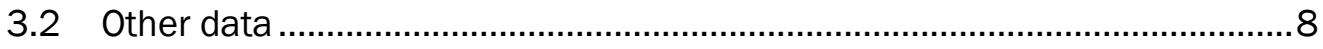

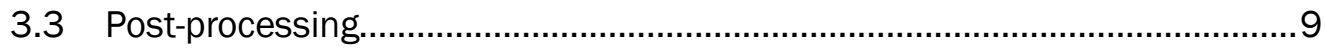

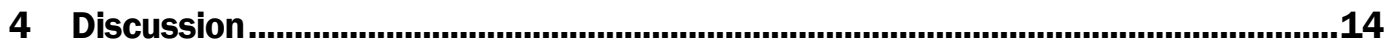

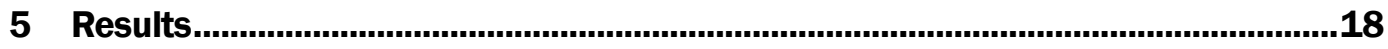

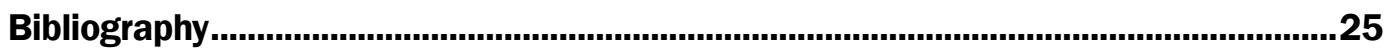

\section{Report Documentation Page}




\section{Figures}

Figure 1. USNH Type 1 - Produced/used from 1840 to February 1862 (VA NCA 2017).

Figure 2. USNH Type 2 - Produced/used from March 1862 to May 1863 (VA NCA, 2017).

Figure 3. USNH Type 3, variation 1 - Produced/used from mid-1863 to 1878 (VA NCA, 2017). 5

Figure 4. USNH Type 3, variation 2 - Produced/used from mid-1863 to 1878 (VA NCA, 2017).

Figure 5. USNH Type 4 - Produced/used from late-1878 to mid-1879 (VA NCA, 2017)

Figure 6. USNH Type 5, variation 1 - Produced/used from mid-1879 to 1945 (VA NCA, 2017). 7

Figure 7. USNH Type 5, variation 2 - Produced/used from mid-1879 to 1945 (VA NCA, 2017). 7

Figure 8. Leica P40 set up at Mt. Moriah Cemetery (ERDC-CERL, 2017).

Figure 9. Point cloud of several scans merged together to create a 3D representation of the headstone (ERDC-CERL, 2017).

Figure 10. Establishment of the reference plane on the surface of the headstone to create the drawing surface (ERDC-CERL, 2017).

Figure 11. Surface of headstone prepared for letter tracing (ERDC-CERL, 2017).

Figure 12. Letters of headstone aligned and traced to highlight original font type(s) (ERDC-CERL, 2017).

Figure 13. Measurements of letters using Cyclone software included spacing from the top of the headstone and between rows of letters (ERDC-CERL, 2017)

Figure 14. Cross section of headstone lettering, used to determine measurements of depth of carving (ERDC-CERL, 2017).

Figure 15: William Keams' headstone, showing two differently styled " $y$ " letters on the same headstone (ERDC-CERL, 2017).

Figure 16. Using the letter "E" as an example, the letters on headstones are not uniform, but show variability in width (ERDC-CERL, 2017).

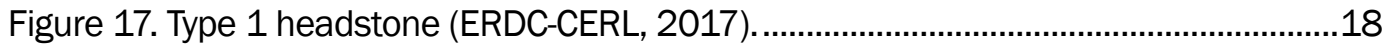

Figure 18. Type 2 headstone (ERDC-CERL, 2017).......................................................... 19

Figure 19. Type 3, variation 1 headstone (ERDC-CERL, 2017)........................................20

Figure 20. Type 3 variation 2 headstone (ERDC-CERL, 2017)..........................................21

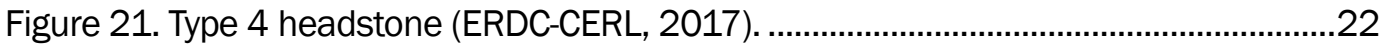

Figure 22. Type 5 variation 1 headstone (ERDC-CERL, 2017). .........................................23

Figure 23. Type 5 variation 2 headstone (ERDC-CERL, 2017). .............................................. 24 


\section{Preface}

This study was conducted for the U.S. Department of Veterans Affairs National Cemetery Administration under Project Number 467132, "3-D Scanning of Military Grave Markers at Mount Moriah Cemetery, Philadelphia PA." The technical monitor was W. Edward Hooker III, Historic Architect/Cultural Resources Manager.

The work was performed by the Land and Heritage Conservation Branch (CNC) of the Installations Division (CN), U.S. Army Engineer Research and Development Center - Construction Engineering Research Laboratory (ERDC-CERL). At the time of publication, Dr. Michael Hargrave was Chief, CEERD-CNC, and Mr. Donald K. Hicks was Acting Chief, CEERDCN. The Interim Deputy Director of ERDC-CERL was Ms. Michelle J. Hanson, and the Interim Director was Dr. Kirankumar V. Topudurti.

The Commander of ERDC was COL Bryan S. Green, and the Director was Dr. David W. Pittman. 


\section{Unit Conversion Factors}

\begin{tabular}{|l|l|l|}
\hline Multiply & By & To Obtain \\
\hline cubic feet & 0.02831685 & cubic meters \\
\hline cubic inches & $1.6387064 \mathrm{E}-05$ & cubic meters \\
\hline degrees (angle) & 0.01745329 & radians \\
\hline feet & 0.3048 & meters \\
\hline inches & 0.0254 & meters \\
\hline microinches & 0.0254 & micrometers \\
\hline microns & $1.0 \mathrm{E}-06$ & meters \\
\hline ounces (mass) & 0.02834952 & kilograms \\
\hline pounds (mass) & 0.45359237 & kilograms \\
\hline square feet & 0.09290304 & square meters \\
\hline square inches & $6.4516 \mathrm{E}-04$ & square meters \\
\hline square yards & 0.8361274 & square meters \\
\hline yards & 0.9144 & meters \\
\hline
\end{tabular}




\section{Methodology}

\subsection{Background}

The site location was Mount Moriah Cemetery in Philadelphia, PA. The cemetery was established by an act of the Pennsylvania Legislature, and it was incorporated on March 27, 1855. ${ }^{1}$ The federal government acquired 10 acres of the cemetery in 1864 for interment of remains buried at Philadelphia's U.S. Naval Home with its first original burial occurring in $1865 .^{2}$ The Navy reinterred 351 remains in February 1866 from the Naval Home's cemetery to the plot in Mount Moriah. The cemetery grew from 54 acres, including public portions, to 380 acres over two large sections. Betsy Ross was once interred at Mt. Moriah before being moved to the Old City (to the courtyard of her historic home) for the 1976 Bicentennial.3 Mount Moriah Cemetery is among Philadelphia's most notable cemeteries, and it is the largest in Pennsylvania.

Much of the private cemetery has suffered from neglect, with overgrown foliage that completely engulfs the headstones in some sections. Over time, headstones have succumbed to weathering, cracking, biological growth, and vandalism. It is unfortunate when headstones crumble and the names, dates, and affiliations become unrecognizable because these monuments of history provide a record of the heroes who served this country with honor and distinction. The naval plot at Mount Moriah has more than 2,400 burial plots for U.S. Navy and Marine Corps officers and enlisted men. ${ }^{2}$

The cemetery was managed by the Mount Moriah Cemetery Association until 2004, when its last known member died.4 In that year, it was named one of the most endangered historic places in Pennsylvania. Eventually,

\footnotetext{
1 History of Philadelphia, 1609-1884, by John Thomas Scharf and Thompson Westcott, Published 1884, L. H. Everts \& Co., Philadelphia, Pa.

2 National Park Service. 2017. Mount Moriah Cemetery Naval Plot and Soldier's Lot Philadelphia, Pennsylvania. https://www.nps.gov/nr/travel/national_cemeteries/pennsylvania/mount_moriah_cemetery_naval_plot_and_soldiers_lot.html.

3 "Corrections," Philadelphia Inquirer (November 22, 2005).

4 Pompilo, Natalie (July 15, 2011). "Abandoned Mount Moriah in grave condition". Philadelphia Inquirer. Retrieved January 21, 2013.
} 
the cemetery closed its gates in 2011. Without ownership, private organizations, volunteers, college students, churches, and family members work to clean up and restore the site. However, it is estimated that annual maintenance costs amount to nearly half a million dollars, making ongoing maintenance a daunting task. The Philadelphia Orphan's Court appointed Mt. Moriah Cemetery Preservation Corporation (a nonprofit, volunteer organization) receivership of the cemetery in $2014 .{ }^{1}$ The cemetery became eligible for listing in the National Register of Historic Places in February $2015 \cdot{ }^{2}$

\subsection{Objective}

This study was conducted in the two central sections of the Naval plot, which is maintained by the U.S. Department of Veterans Affairs (VA). The VA intends to replace many of the headstones with new ones. To preserve their historical integrity, aspects of the existing headstones including specific lettering, spacing, and wording will be preserved on the new headstones. The objective of this study was to use $3 \mathrm{D}$ laser imaging to collect specifics of lettering fonts and placement for appropriate replication.

\subsection{Researchers}

This project was conducted by the U.S. Army Corps of Engineers, Engineering Research Development Center, Construction and Engineering Research Laboratory (ERDC-CERL), based in Champaign, IL. The research team included Carey Baxter, Archeologist with 21 years of experience; Andrew Hamblin, Research Ecologist with 17 years of experience; and Dr. Susan Enscore, Geographer, as project manager with 25 years of experience. automated computer-aided design (Auto-CAD) assistance was provided by Brandy Diggs and Eric Kreiger, both at ERDC-CERL.

\subsection{Site visits}

The site of this study was the U.S. Naval Plot in Mount Moriah Cemetery, Philadelphia, PA. The military cemeteries are divided by services into four

\footnotetext{
${ }^{1}$ Bixler, Michael "Mount Moriah Now Under New Management." Hidden City, PA website, https://hiddencityphila.org/2014/09/mt-moriah-now-under-new-management/ (22 September 2017). 2 Preservation Alliance for Greater Philadelphia. 2015. Mount Moriah Cemetery Gatehouse. http://www.preservationalliance.com/place-to-save/mount-moriah/
} 
major sections at Mount Moriah Cemetery. This study included the Sections 2 and 3, where "beneficiaries" of the Naval Home were buried. While several standard government headstones exist in these sections, the majority of the headstones were procured from local monument companies by the Naval Home. A site visit was made by project researchers during 24-28 July 2017 to conduct scanning. 


\section{Study Materials}

The Naval Plot at Mount Moriah Cemetery contains five sections. The smallest, section 5, is the "Officers' Section." Section 1 is often referred to as the "Naval Yard" section or the "Young Men's Section;" it contains the remains of activity duty personnel who died in the Philadelphia area or retired Navy and Marine servicemen who were not residents of the Naval Home. Sections 2-4 contain the remains of U.S. Naval Home "beneficiaries"-men who were no longer able to work or care for themselves due to sickness or injury incurred in the line of duty. This study included Sections 2 and 3, where dates of death range from circa 1830 to the early part of the twentieth century.

Personnel from the VA's National Cemetery Administration selected the initial headstones to be scanned and imaged for replication of their fonts. There were five lettering types, with both Type 3 and Type 5 having two additional variations.

The headstones selected for this project are all from burials related to the U.S. Naval Home. The various types can be seen in the following images (Figure 1-Figure 7).

Figure 1. USNH Type 1 - Produced/used from 1840 to February 1862 (VA NCA 2017).

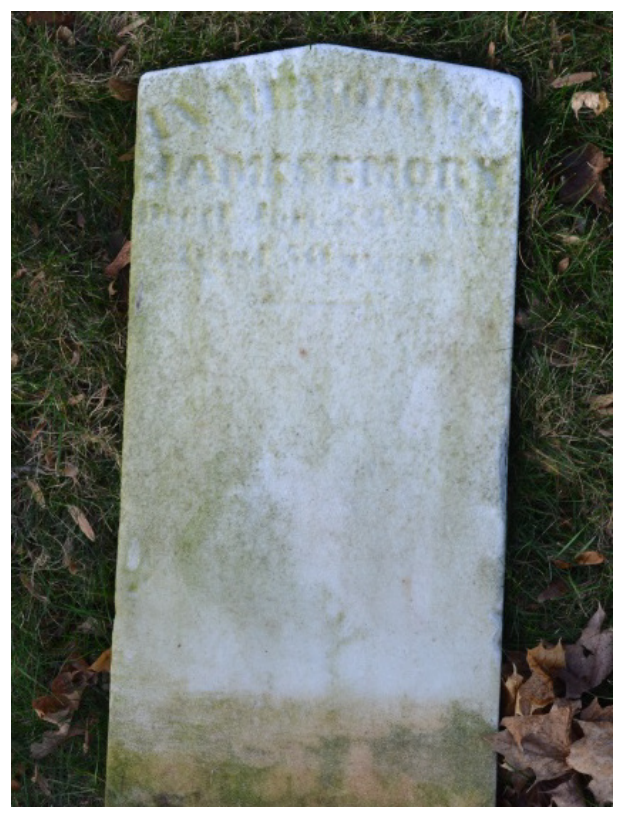


Figure 2. USNH Type 2 - Produced/used from March 1862 to May 1863 (VA NCA, 2017).

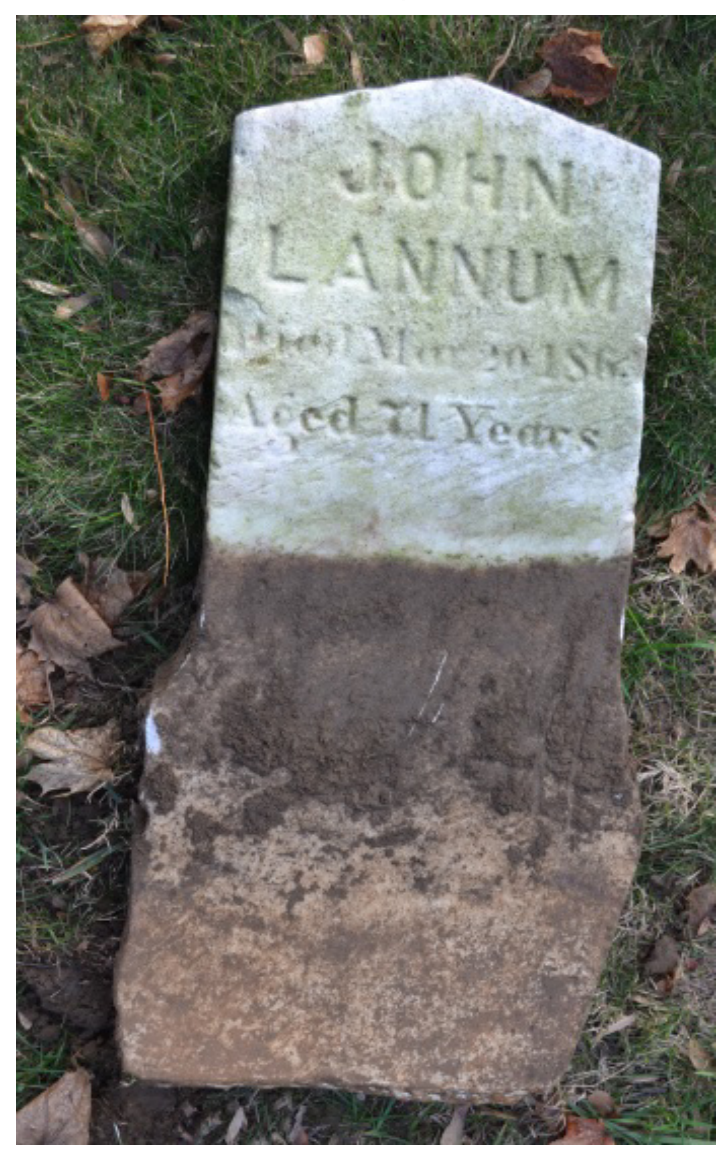

Figure 3. USNH Type 3, variation 1 - Produced/used from mid-1863 to 1878 (VA NCA, 2017).

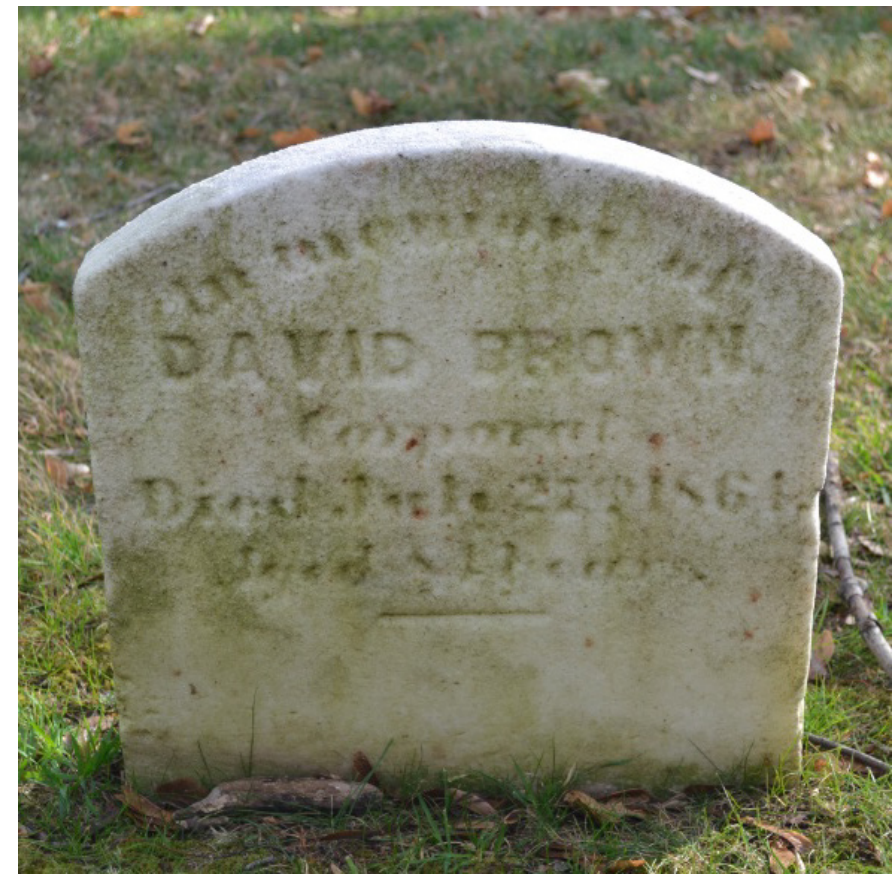


Figure 4. USNH Type 3, variation 2 - Produced/used from mid-1863 to 1878 (VA NCA, 2017).

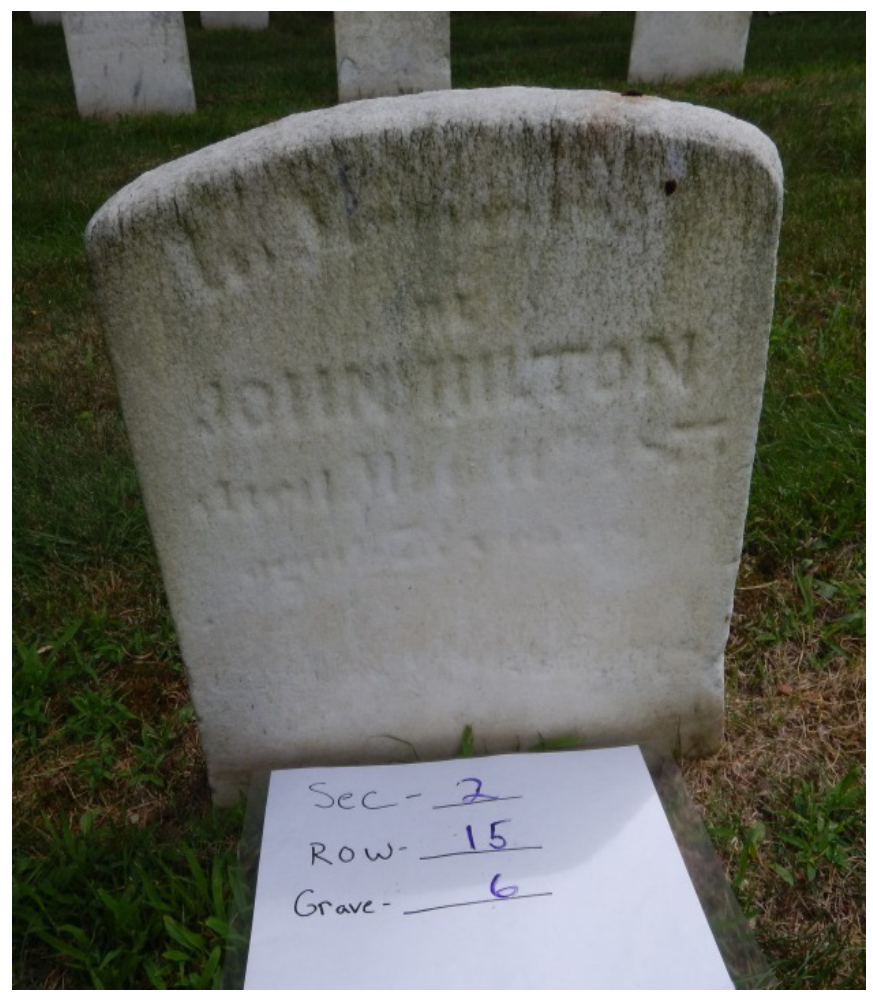

Figure 5. USNH Type 4 - Produced/used from late-1878 to mid-1879 (VA NCA, 2017).

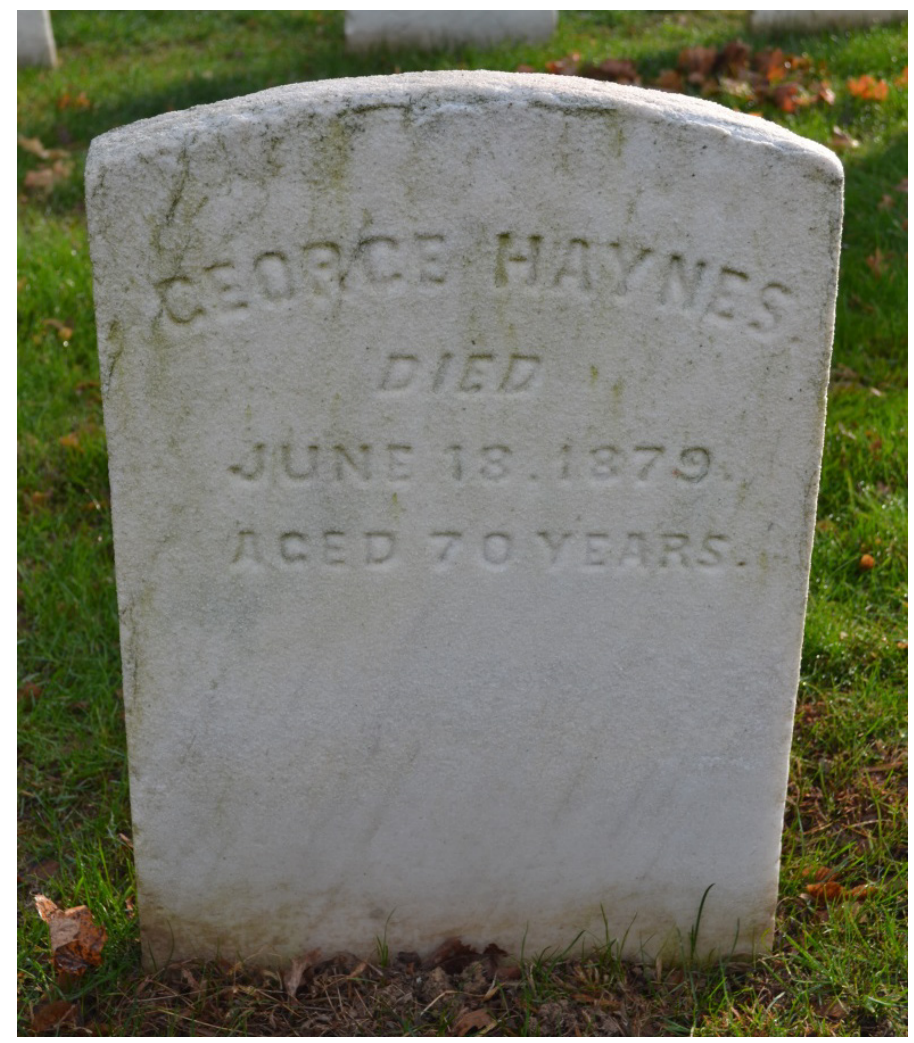


Figure 6. USNH Type 5, variation 1 - Produced/used from mid-1879 to 1945 (VA NCA, 2017).

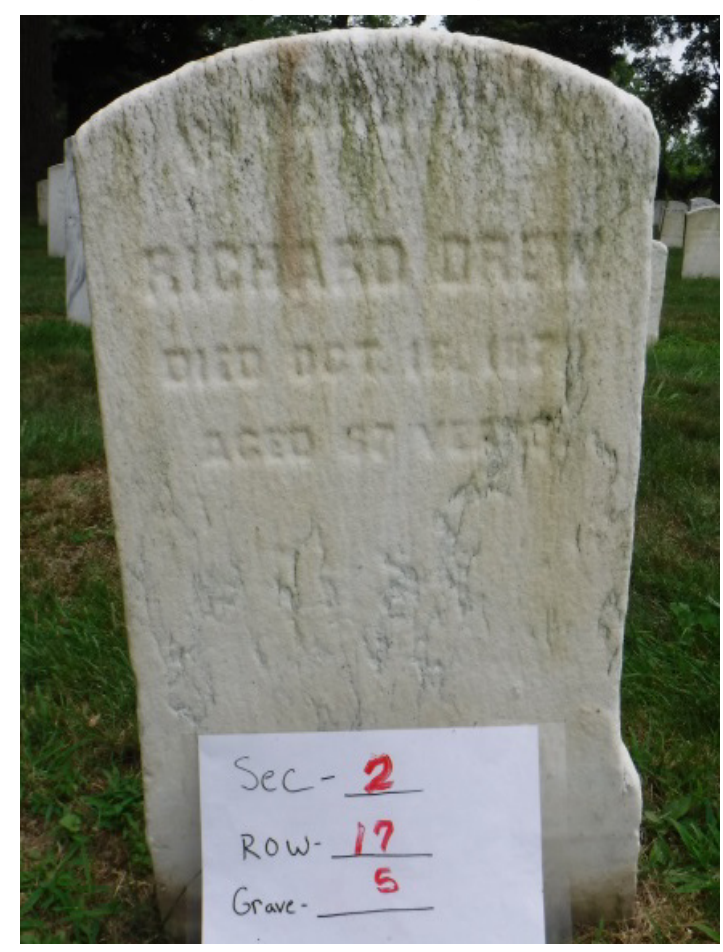

Figure 7. USNH Type 5, variation 2 - Produced/used from mid-1879 to 1945 (VA NCA, 2017).

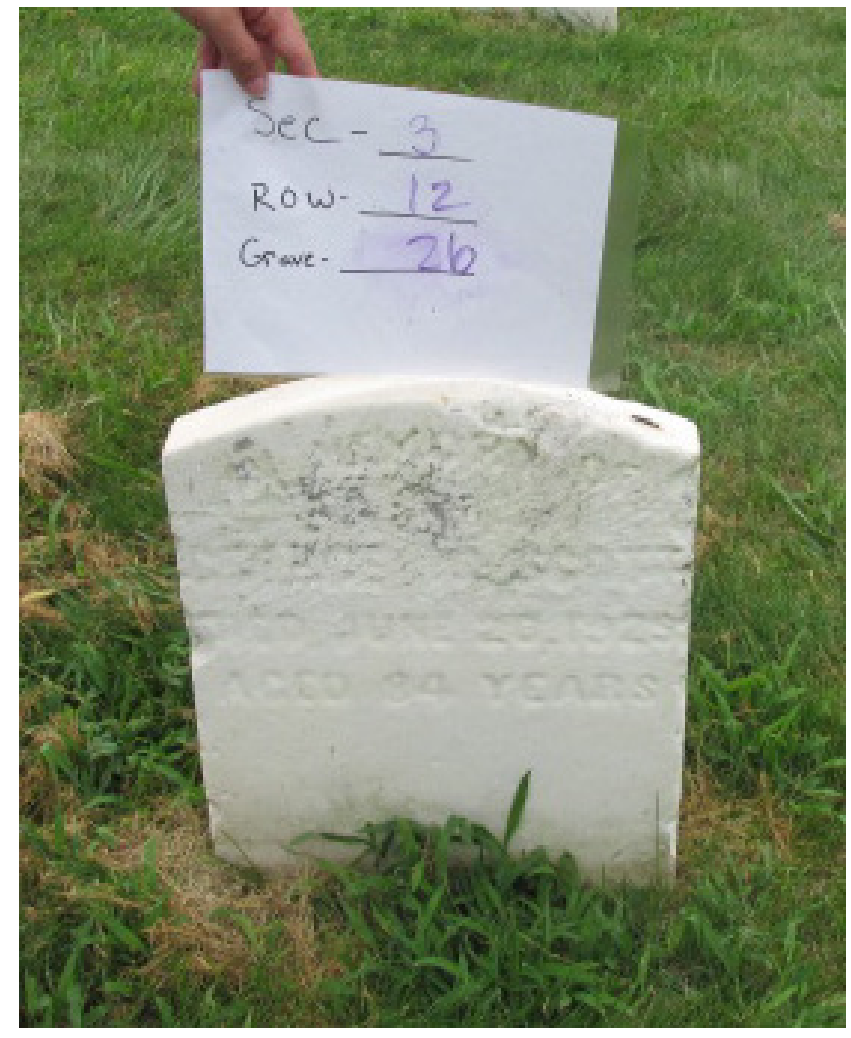




\section{Data Gathering and Processing}

\subsection{D imaging}

The scanner used was the Leica $\mathrm{P} 40$ laser scanner, set at a resolution of 3.1 $\mathrm{mm}$ at $10 \mathrm{~m}$. The scanner was mounted on an engineering-grade survey tripod and placed along the row facing the intended headstone(s) (Figure 8). Scans were taken from the direct front, front-left, and front-right (30$45^{\circ}$ angle). A custom field of view $\left(135^{-180^{\circ}}\right)$ was imaged with overlap so that the constraint algorithm was satisfied with the software. Both laser point clouds and digital images were collected from the scanner. Images were taken from 25-27 July 2017 in conditions ranging from drizzling rain to sunny skies.

Figure 8. Leica P40 set up at Mt. Moriah Cemetery (ERDC-CERL, 2017).

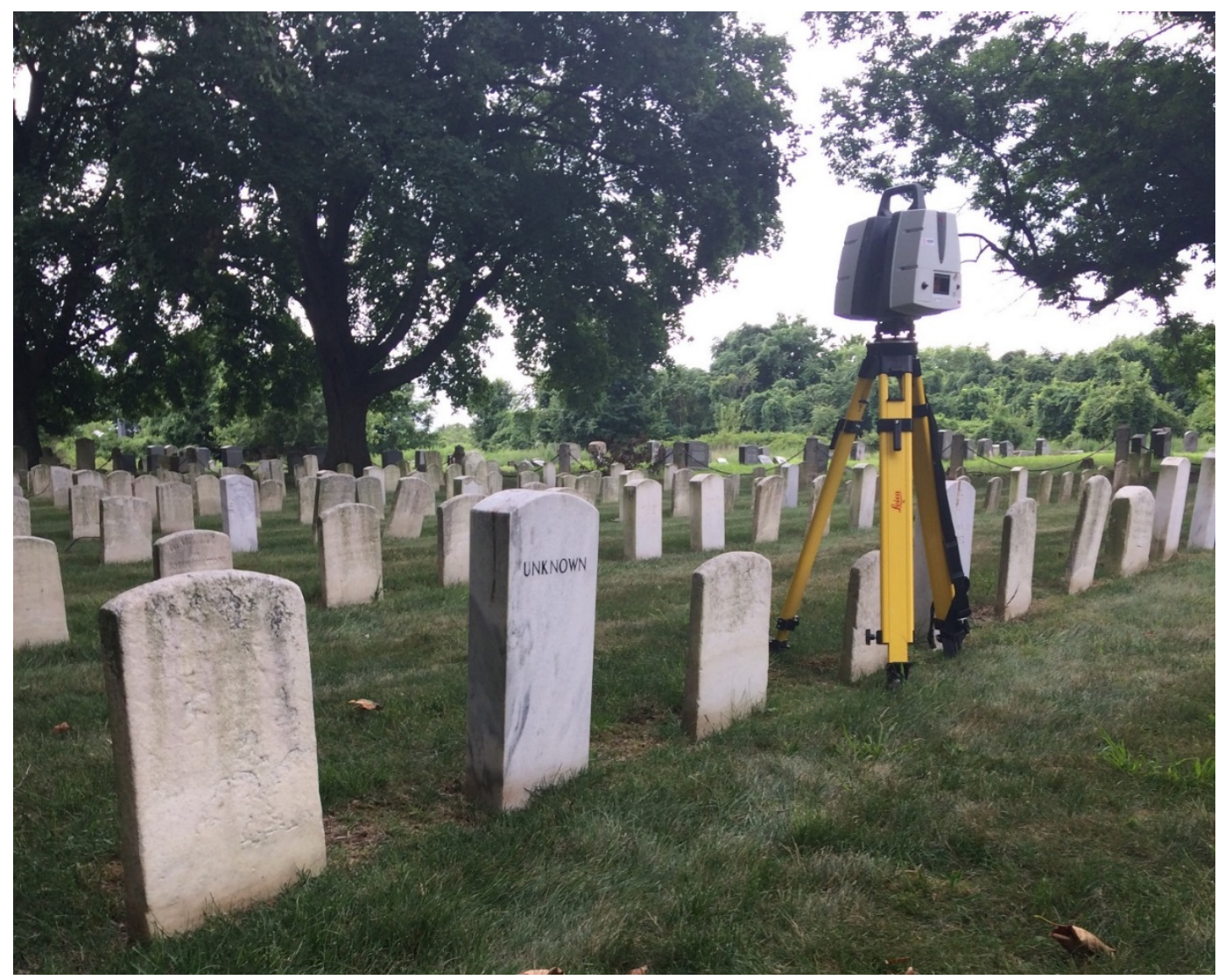

\subsection{Other data}

Rubbing with chalk on a cloth layer was attempted on one headstone to create a representation of the lettering. Caliper measurements were taken 
of lettering width, height, and depth for a representative sample of all headstone types.

\subsection{Post-processing}

Data was transferred from the scanner to external hard drives for verification and digital backup every evening. Registration of scans was performed in Leica Cyclone 9.1.3 software, upon returning to ERDC-CERL's research lab (Figure 9). In this process the scan points from the individual scans are visually aligned using common reference points and then merged into a single point cloud.

Modeling was then used to create lettering for each headstone. First, the scan data for the stone surface was isolated from the larger point cloud, and a reference plane was established on the face of the stone (Figure 10). None of the headstones were perfectly vertical in their alignment. Using the reference plane as the drawing surface enabled the researchers to rotate the point cloud to achieve the best view of each letter without affecting the aspect, ratio, or scale of the traced letters. Separate drawing layers were created for letters and guidelines (used to ensure the correct orientation of the letters to each other and to the edges of the headstone). For some headstones, the visualization of the letters was enhanced by making a solid mesh surface of the point cloud (Figure 11). Figure 12 illustrates a headstone after the tracing has been completed. Once tracing was finished, the drawing layers were turned off, and measurements were taken of letter heights and spaces between guidelines (Figure 13). Lines of lettering were isolated and rotated to be viewed in cross section to determine the depth of carving of each line of letters (Figure 14). 
Figure 9. Point cloud of several scans merged together to create a 3D representation of the headstone (ERDC-CERL, 2017).

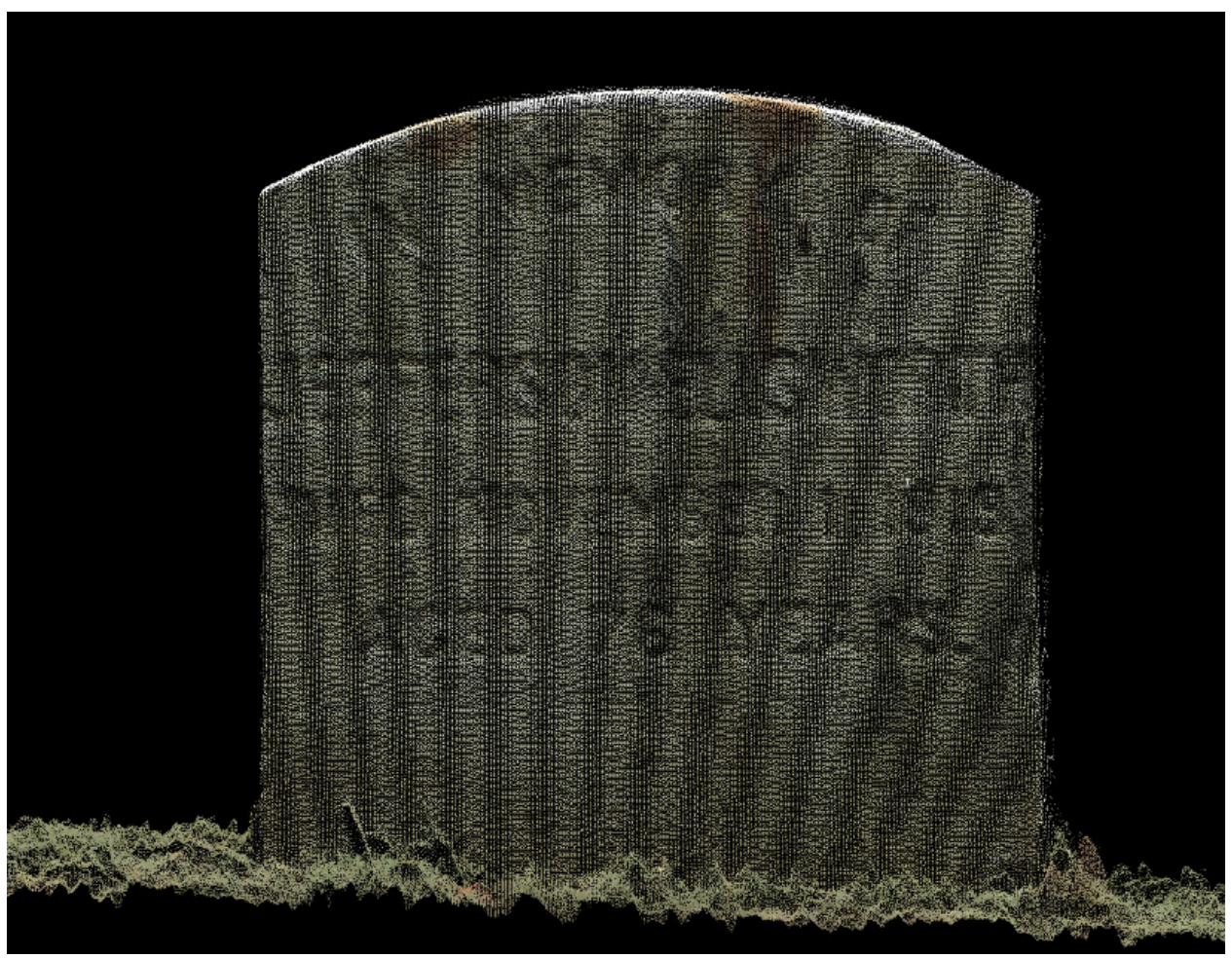

Figure 10. Establishment of the reference plane on the surface of the headstone to create the drawing surface (ERDC-CERL, 2017).

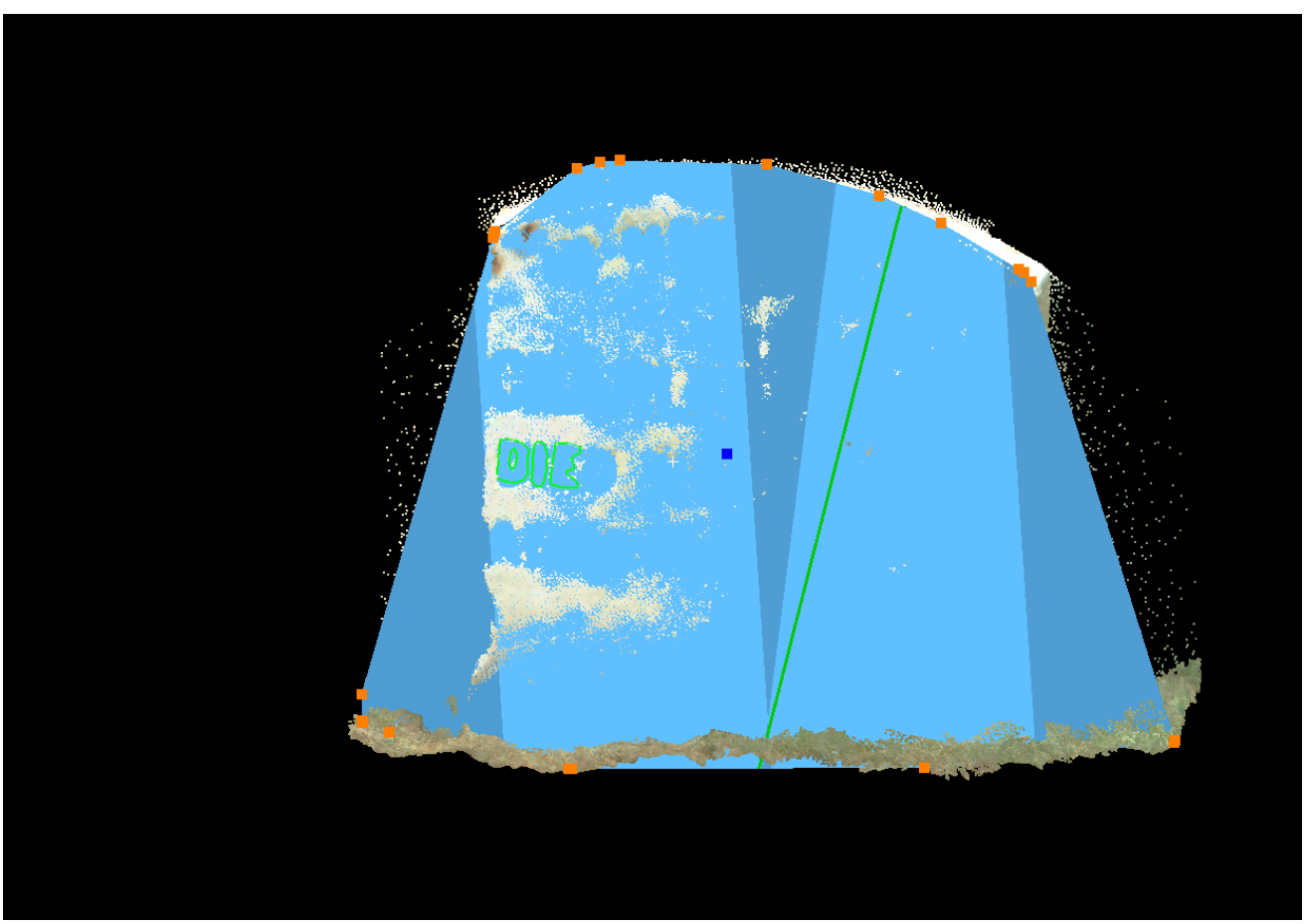


Figure 11. Surface of headstone prepared for letter tracing (ERDC-CERL, 2017).

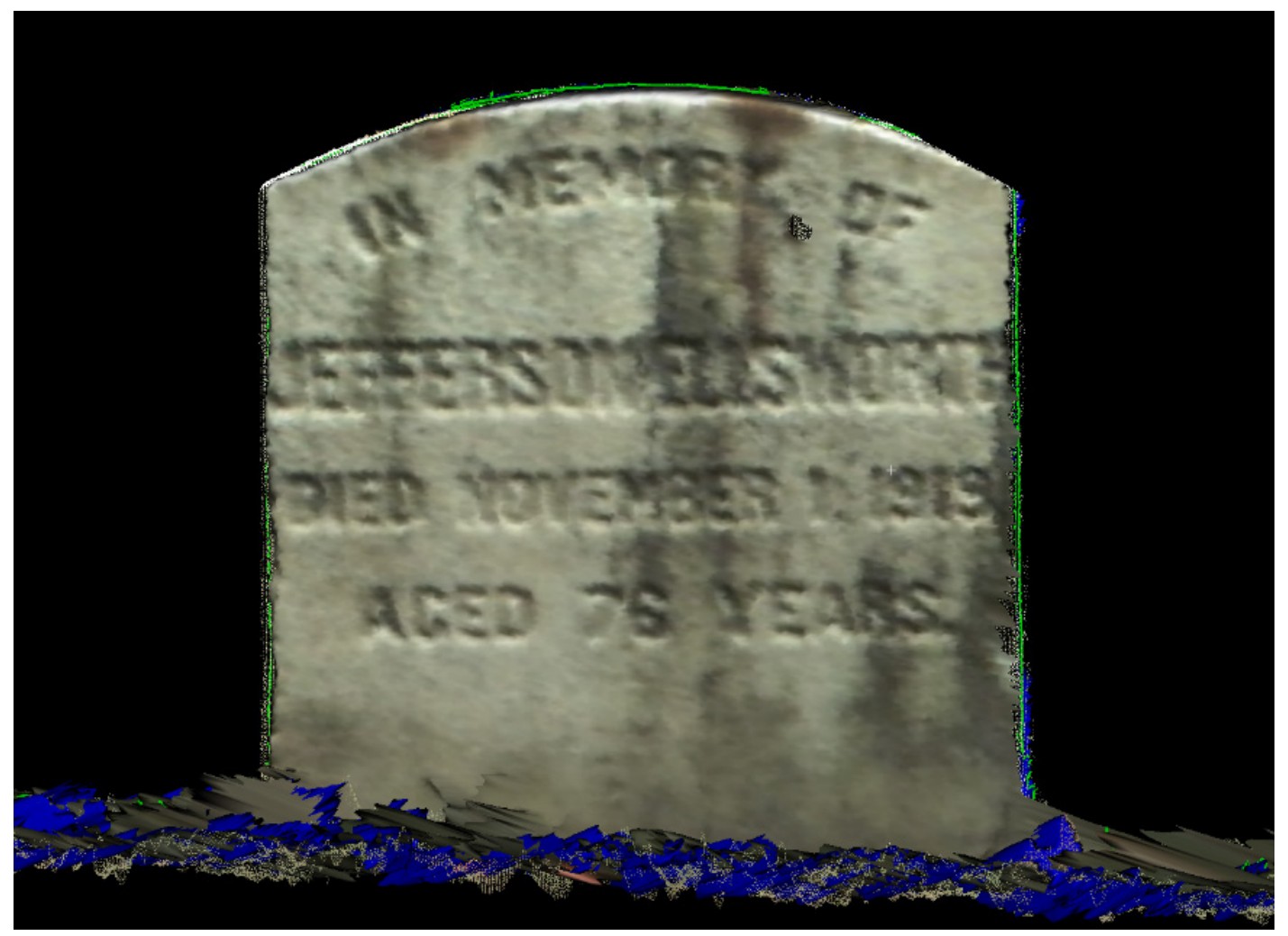

Figure 12. Letters of headstone aligned and traced to highlight original font type(s) (ERDC-CERL, 2017).

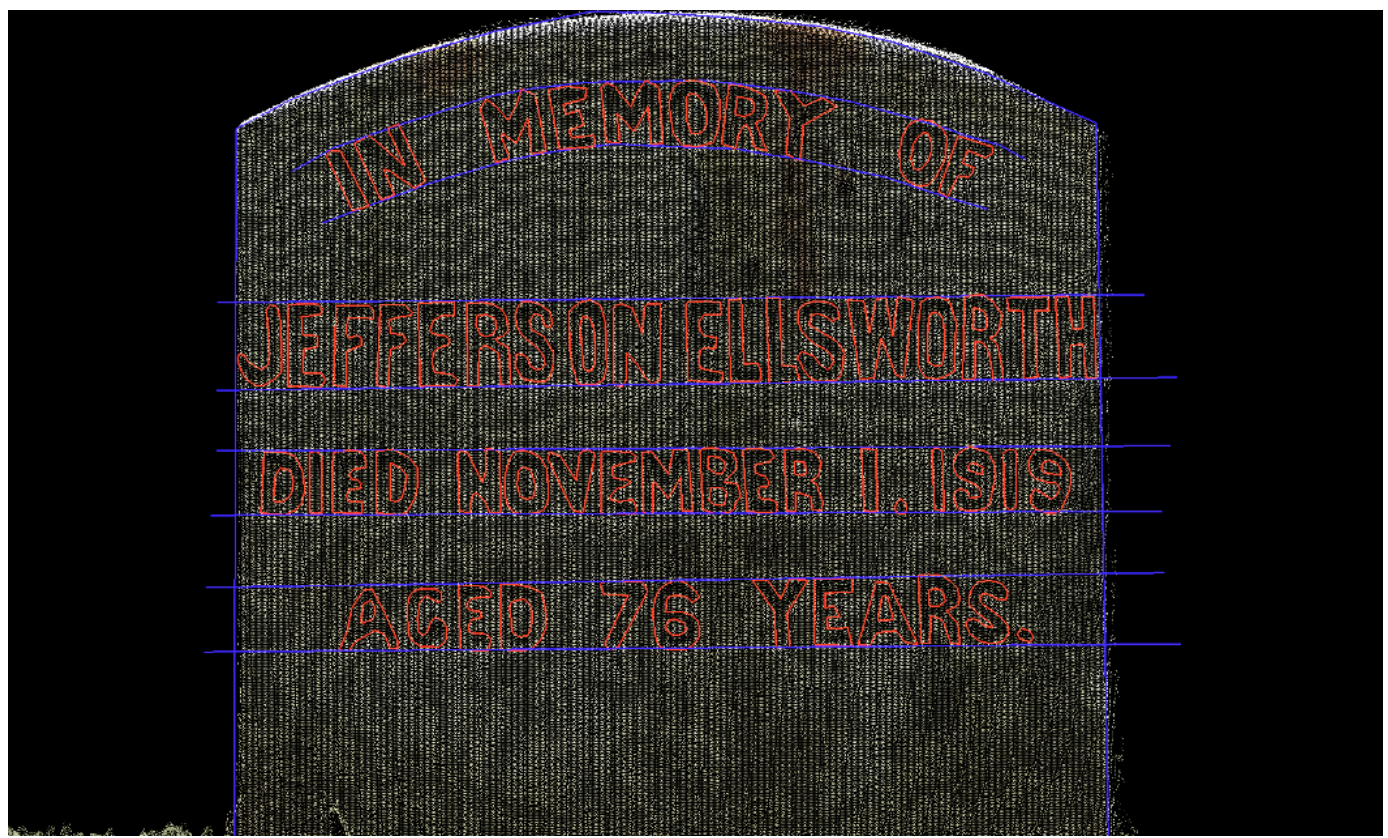


Figure 13. Measurements of letters using Cyclone software included spacing from the top of the headstone and between rows of letters (ERDC-CERL, 2017).

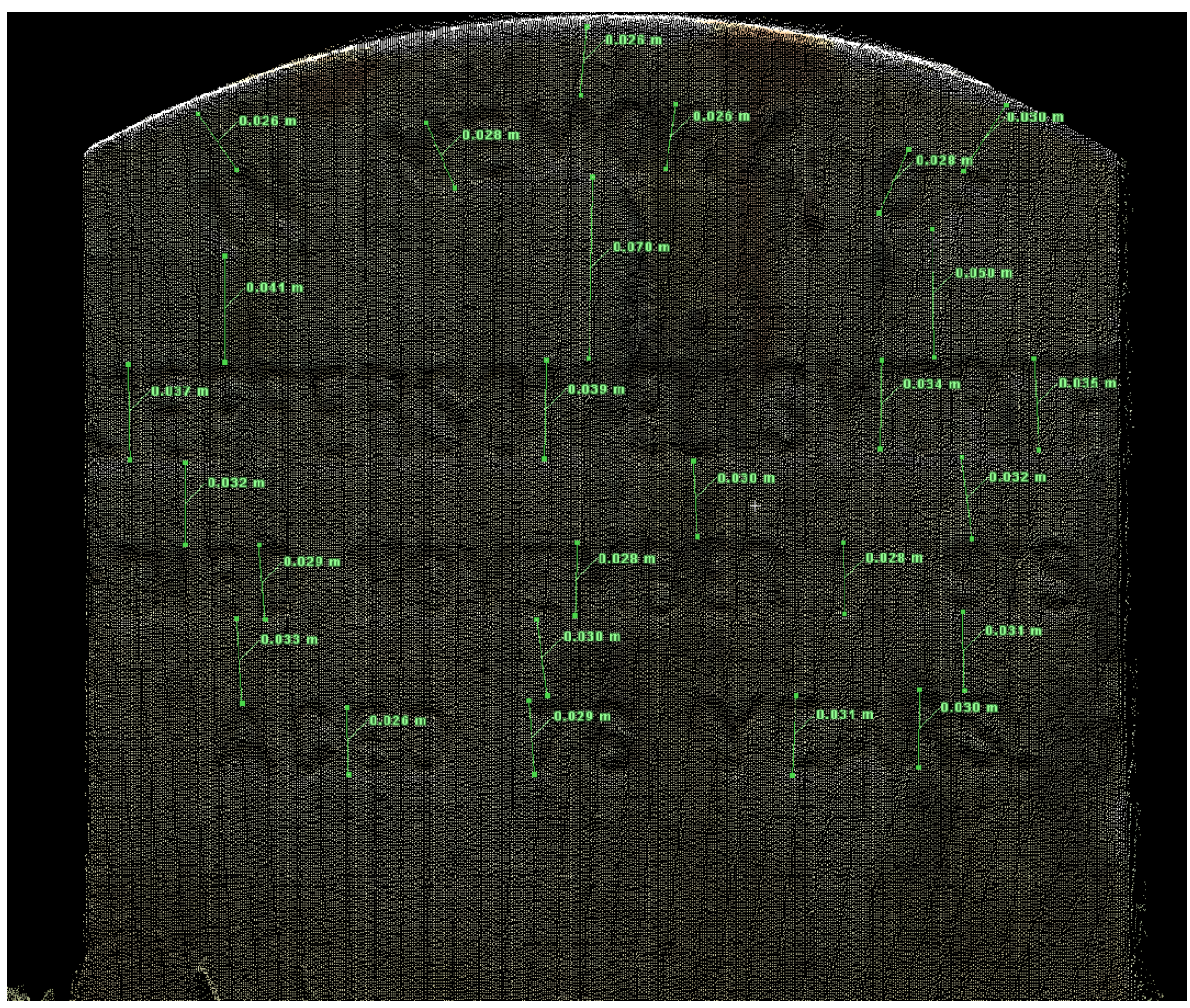

Figure 14. Cross section of headstone lettering, used to determine measurements of depth of carving (ERDC-CERL, 2017).

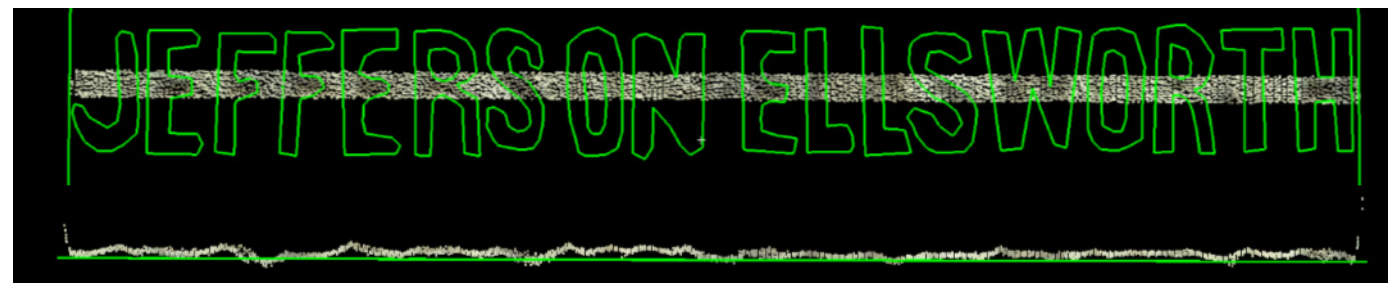

The objective of this effort was to create a standardized font and to erase the effects of erosion. It was determined after tracing just a couple stones that a simple export to computer-aided design (CAD) software of the drawn layers would be insufficient to meet these goals; there were missing letters in each font, in addition to too much irregularity in the lettering due both to erosion of the stone and variations in the original carving of the letters. Additionally, the Cyclone software did not have an optimal set of drawing tools that would enable the creation of standardized arcs and cir- 
cles. It was determined that a second software package was needed to process the letter tracings. Thus, the scan tracings were exported into ESRI ArcGIS. ${ }^{1}$

Once in ArcGIS, the traced letters were compared against the more than 440 font options within the software. The comparison was done letter by letter to ensure the best match for each letter type on the headstones. The alphabets generated by ERDC-CERL in this project include portions of at least two, and in one case as many as five, of the fonts in ArcGIS. In some cases, no font could be found for particular letters (lowercase a, $\mathrm{g}, \mathrm{j}$ and uppercase $G$ and $J$ proved the most problematic) and in those cases, the letter was drafted by using parts of letters that did have a good fit. A lowercase "a" for example could be approximated from the bottom of a "d" and the top of a "p." The result generated the best approximation of what each headstone font would have looked like prior to erosion, to include all letters (even those that were not present on any scanned stone). Once the customized font for each stone type was generated in a geographic information system (GIS) format, it was compared to the point cloud scans and to photographs of the headstones, and then adjustments to the fonts were made to ensure the best possible match. The resulting headstone lettering fonts were then exported into $\mathrm{CAD}$ for final formatting.

\footnotetext{
${ }^{1}$ Any advanced drawing, mapping, or drafting software could have been used for this purpose. ArcGIS was used in this instance because the researchers already had it installed on their computers and were very familiar with the drawing and measuring functions in that software suite.
} 


\section{Discussion}

The process of scanning headstones was straightforward. The uniform layout of headstones makes for a routine process that is quite efficient. Instead of attempting to make a single unified point cloud of entire cemetery sections, each headstone (or small groups of headstones) was scanned individually and 19 smaller point clouds were generated. While the 3D laser is capable of taking images in darkness, rain, and other environmental conditions, digital imaging requires natural or artificial light to work effectively. The point cloud is the most important aspect of this technology for recreating the headstone fonts, but the coloring from the images helps in visualization, presentation, and outreach.

For this project, the decision was made in the field to collect each scan as a $180^{\circ}$ arc instead of a full $360^{\circ}$ circle. This decision was made to shorten the scanning time (enabling more scans to be taken) and to reduce the number of unnecessary data points collected. After the field scanning was complete and serious data processing was underway, it was discovered that this decision was not optimal. In many cases, the scans would not properly align. The error was in a range of $1.5-1.7 \mathrm{~cm}$, and the error was always in the direction of the missing $180^{\circ}$ of data. It was determined that while the area on the opposite side of the scanner from the headstones might have no use in the analysis of the headstone fonts, that area did provide critical reference points to ensure proper registration of the scans in all three dimensions. It is therefore recommended that all future efforts of this type should be scanned with a full $360^{\circ}$ of data collection.

The result of the $180^{\circ}$ scans was that in the registered point clouds, the stones appeared to have multiple faces that are fractions of centimeters apart from each other, and the engraved letters become illegible. By the time the error was discovered, no time or resources were available to return to the cemetery and repeat the scans. As a result, many of the fonts had to be traced from the individual scans instead of from the combined registration of three scan. The tracings were then combined to create a registered trace. This method resulted in longer data processing times. While it is not felt that the finalized fonts generated by these scans were compromised, many of the point clouds of the headstones will not be easily viewable when using the most common freeware point cloud software 
nor will they be usable as visual aids for public outreach. It is recommended that for any future scanning project of tombstones, all scans should include a full $360^{\circ}$ of data collection.

The goal of this project was to generate a record of the standardized fonts used on the headstones at Mount Moriah cemetery. Examinations of the stones demonstrated that there wasn't any single standardized font used on any headstone at the cemetery. Each headstone had originally been hand carved, and variations occurred in lettering between and within headstones. One example of this variation is that two different styles of lowercase " $y$ " appear on the Type 2 headstone belonging to William Keams (Figure 15).

Figure 15: William Keams' headstone, showing two differently styled "y" letters on the same headstone (ERDC-CERL, 2017).

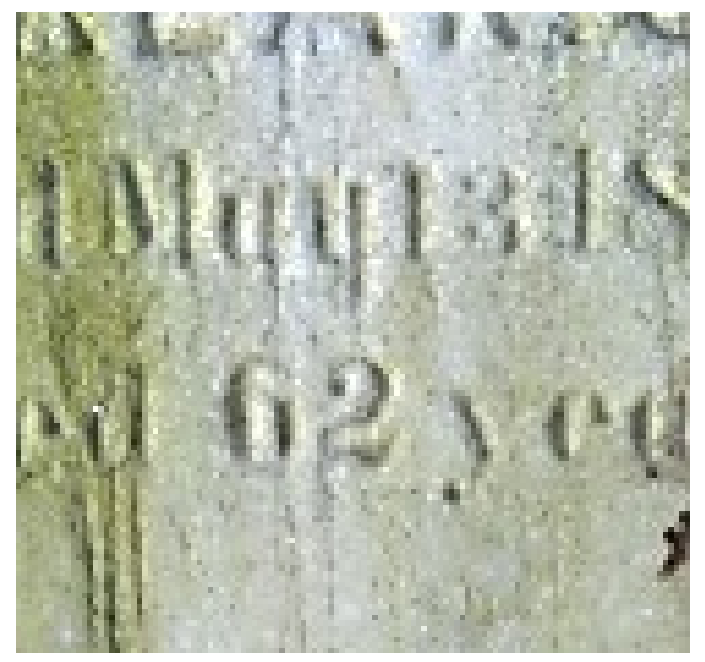

Within each headstone type, there was virtually no variation in the height of the letters and the spacing between the lines of letters. But there was a very large variety in the width of letters between headstones of the same type and even within a single headstone. It appears that to fit longer names onto single lines of text, the carvers would not only place the letters closer together but they also would decrease the width of individual letters. Charles Henry's Type 5 headstone was the same width as Jefferson Ellsworth's and Benjamin Alderman's, but the latter had to contain many more letters. The widths of the "R" varied from $1.4 \mathrm{~cm}$ in Jefferson, $2.0 \mathrm{~cm}$ in Alderman, and $2.8 \mathrm{~cm}$ in Charles. The variations were even visible within single names. Figure 16 illustrates an example of this. The headstone is a Type 5 belonging to Jefferson Ellsworth. There is $22 \%$ variation in the widths of the letter " $\mathrm{E}$ " on the name line, and a $27 \%$ variation in the 
same letter "E" on the date of death line. The first "E" in November is wider than the one in Ellsworth, despite the fact that the name font is supposed to be significantly taller than the date-of-death font. The use of preexisting font types in ArcGIS as guides enabled the researchers to generate standardized fonts where the letters were uniform in width. When generating the engravings on the replica headstones, the modern-day carvers also will need to adjust the widths of the letters to fit the names and dates within the available width of the stones.

Figure 16. Using the letter "E" as an example, the letters on headstones are not uniform, but show variability in width (ERDC-CERL, 2017).

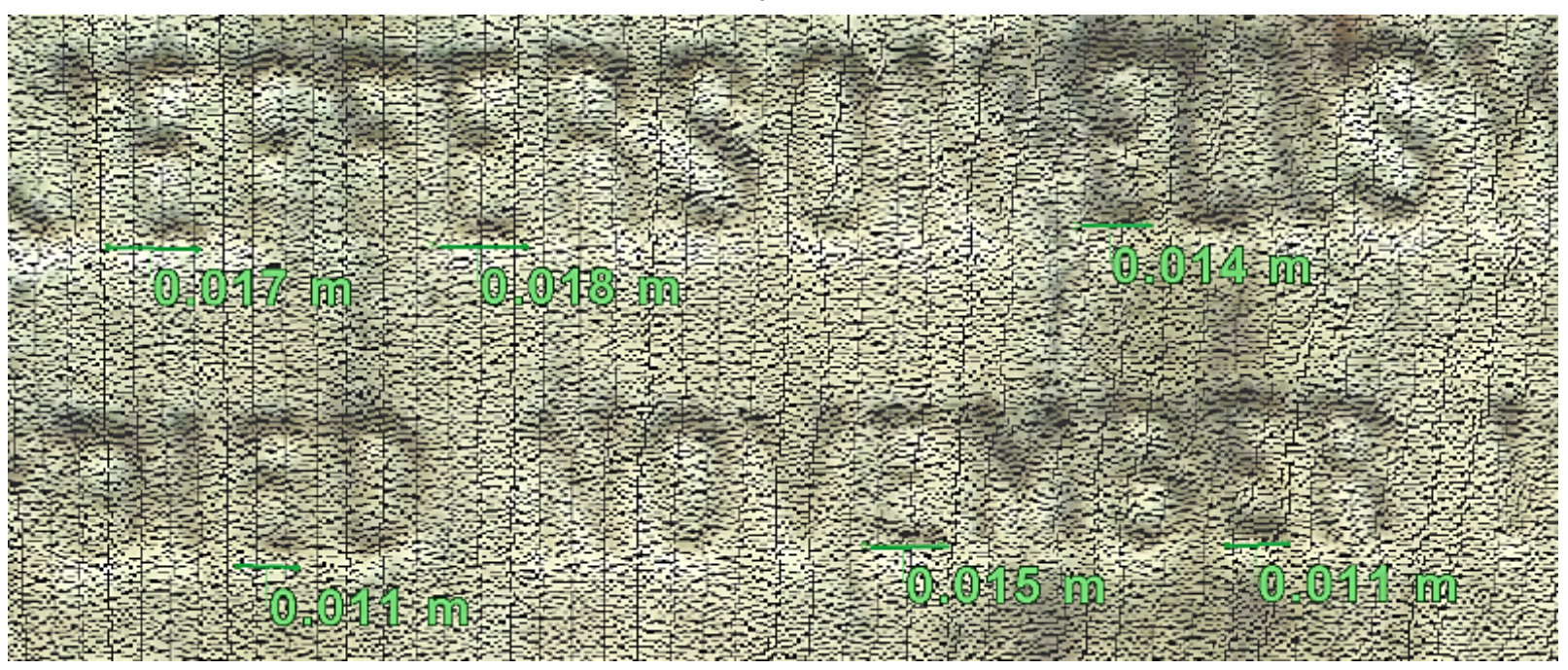

Other methods of capturing headstones inscriptions have been used in the past. Pictures taken with film or digital cameras are useful. Additional photos were not taken since the scanner also takes digital images. However, having backup images taken with a digital single-lens reflex (dSLR) camera may be useful due to the better quality of the lenses and optics of the dSLR camera, compared to the camera included in the scanner. The images taken with the Leica $\mathrm{P} 40$ scanner were mostly useful for coloration of the $3 \mathrm{D}$ point clouds, but the images tended to pixelate quickly when zoomed in on.

Rubbings were attempted in this study as another form of reference, but the width of the letters and the rounded edges caused by erosion of the headstones made the rubbings illegible. If this type of project (font re-creation) is attempted for other headstone types, it is possible that stones with crisper carving edges might produce better results with the rubbing technique. 
Targets are important in 3D laser imaging for referencing and auto-referencing individual $3 \mathrm{D}$ scans into a single point cloud. This study employed three Leica High-Definition Surveying 6-inch targets with scan. However, the targets need to be very stable and not move during the process, and they need to be located in different spatial planes to be effective. Additionally, it is recommended that at least one target be placed behind the scanner to facilitate the most accurate $3 \mathrm{D}$ registration of data.

One way to possibly make transition time faster would be to use a rolling dolly or cart stable enough to resist wind or other disturbances. This could be possible on the flat terrain found at Mount Moriah cemetery. Then the scanner wouldn't need to be dismounted, tripod moved, and the scanner remounted again for each transition. Indoors, a rolling tripod dolly is used in similar fashion so that the entire unit with the scanner can be moved quickly from room to room. Only minor adjustments to level the scanner would be needed.

Security of personnel during laser scanning is something to consider for any survey crew. While Mt. Moriah is a gated cemetery, it is still located within a large urban environment. Dogs off leash, curious youth, and even concerned citizens interrupted the scanning process. A police patrol would come through occasionally when the gates were left open by groundskeepers. Work also had to be curtailed when contract landscapers came to mow and landscape. To safeguard against issues of authorization and trespassing, it is suggested to have government travel orders, to have written authorization from owners, to carry identification, and to wear appropriate bright, reflective survey gear or other definitive work clothing.

Overall, $3 \mathrm{D}$ laser imaging is potentially the best possible way to approach this project. The addition of other software accessories such as ARC/GIS, AutoCAD, Adobe Photoshop, and a graphical writing tablet are helpful as well. Working closely with the stone cutter of interest is also useful for identifying what specific form of media needs to be provided to do the actual cutting, whether by hand template or automated system. 


\section{Results}

A total of 67 scans were taken for the 19 sets of headstones. Some sets included more than two headstones, so they were included in the same group of scans. Each laser scan with digital image array took from 8 to 10 minutes, depending on light availability. Total imaging time amounted to about 17 hours with 569 gigabytes (GB) of data produced following processing. The complete data and suggested font types are provided in digital format (see Figure 17 to Figure 23). Lettering templates, whether arched or linear, distances from the top of the headstone, and distances between rows are also provided.

Figure 17. Type 1 headstone (ERDC-CERL, 2017).

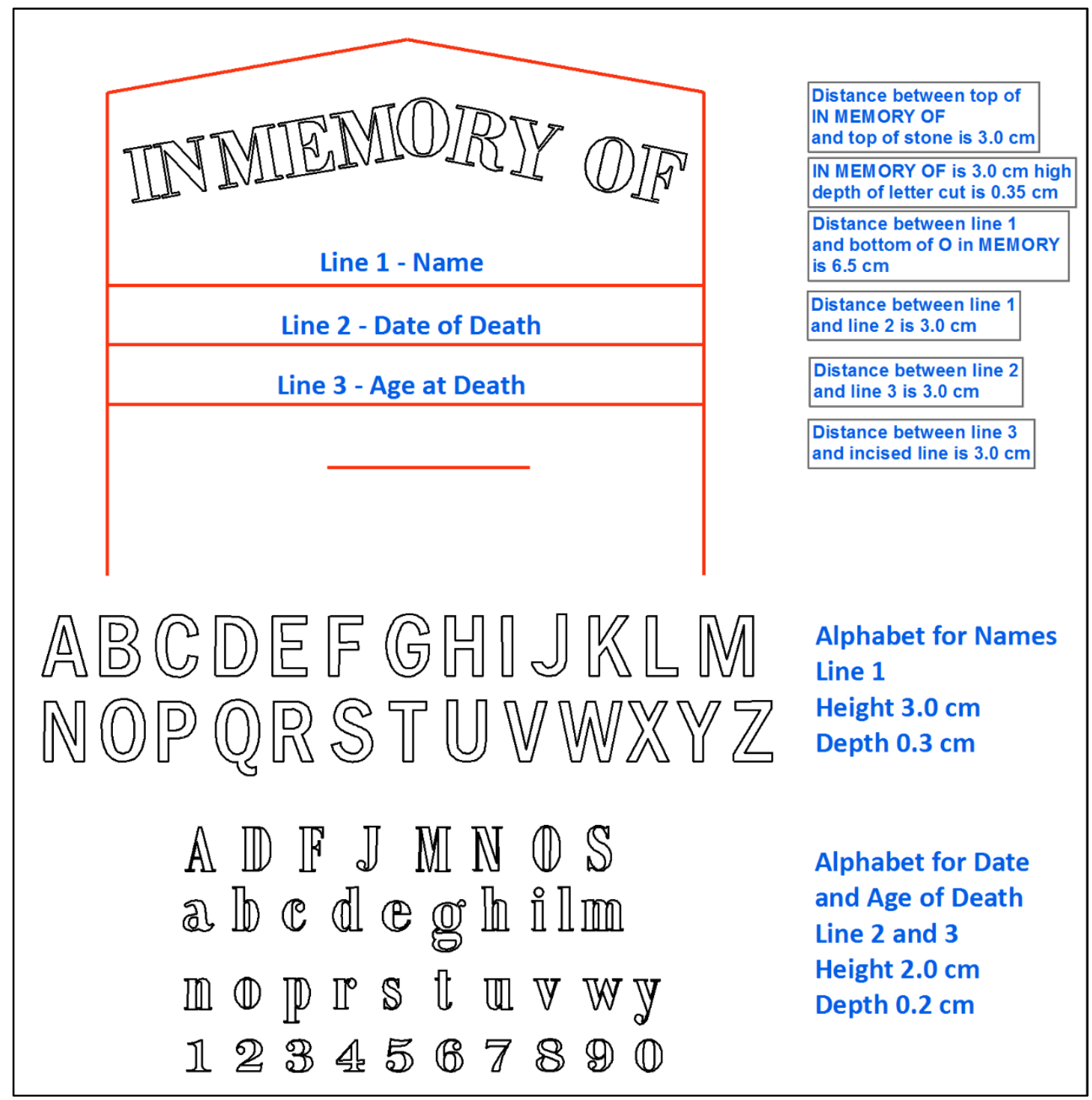


Figure 18. Type 2 headstone (ERDC-CERL, 2017).

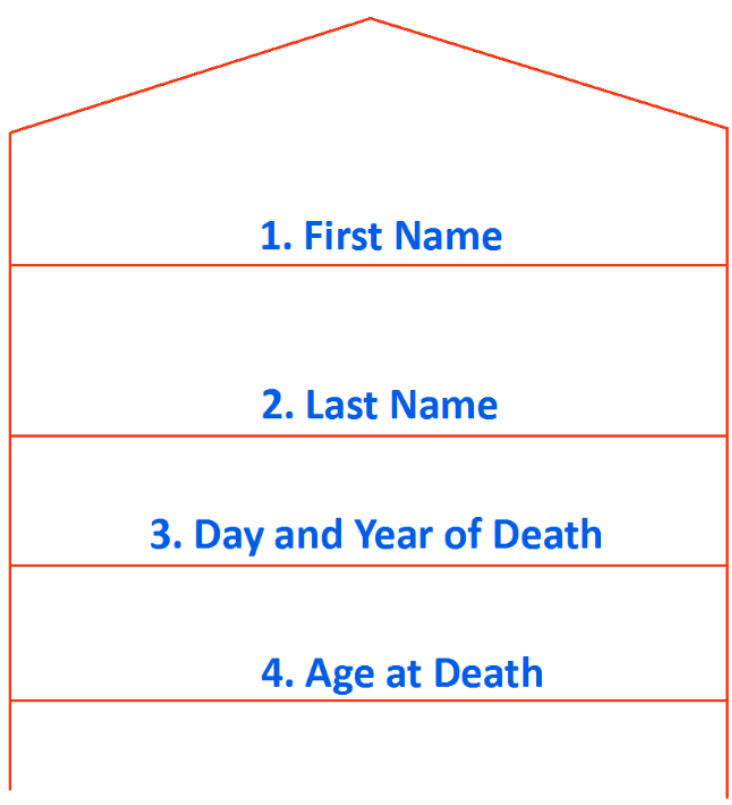

Distance from Line 1 to peak of stone (on center line) is $9.0 \mathrm{~cm}$

Distance from Line 1 to Line 2 is $6.5 \mathrm{~cm}$

Distance from Line 2 to Line 3 is $5.0 \mathrm{~cm}$

Distance from Line 3 to Line 4 is $5.0 \mathrm{~cm}$

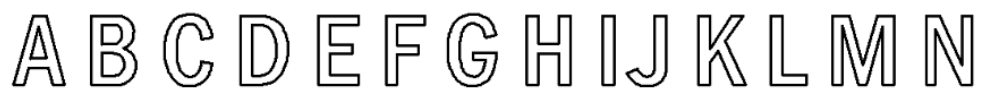

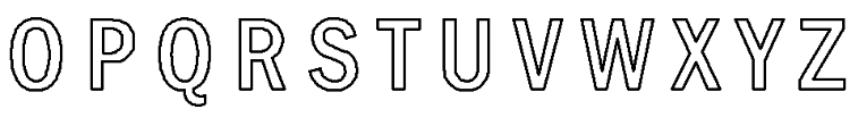

$\mathbb{A} \mathbb{D} \mathbb{I} \mathbb{M} \mathbb{N} \mathbb{S} \mathbb{Y}$

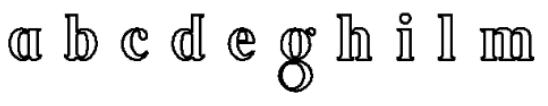

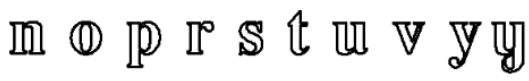

11234569890

1124567890
Alphabet for Name Height $3.8 \mathrm{~cm}$ Depth $0.25 \mathrm{~cm}$
Alphabet and Numbers for Year and Age of Death * Height $2.6 \mathrm{~cm}$ Depth $0.25 \mathrm{~cm}$

* $y$ has 2 lowercase fonts. The rounded one appears in "May"

on Keams grave line3 triangular one appers in "years" on

Keams grave line 4 
Figure 19. Type 3, variation 1 headstone (ERDC-CERL, 2017).

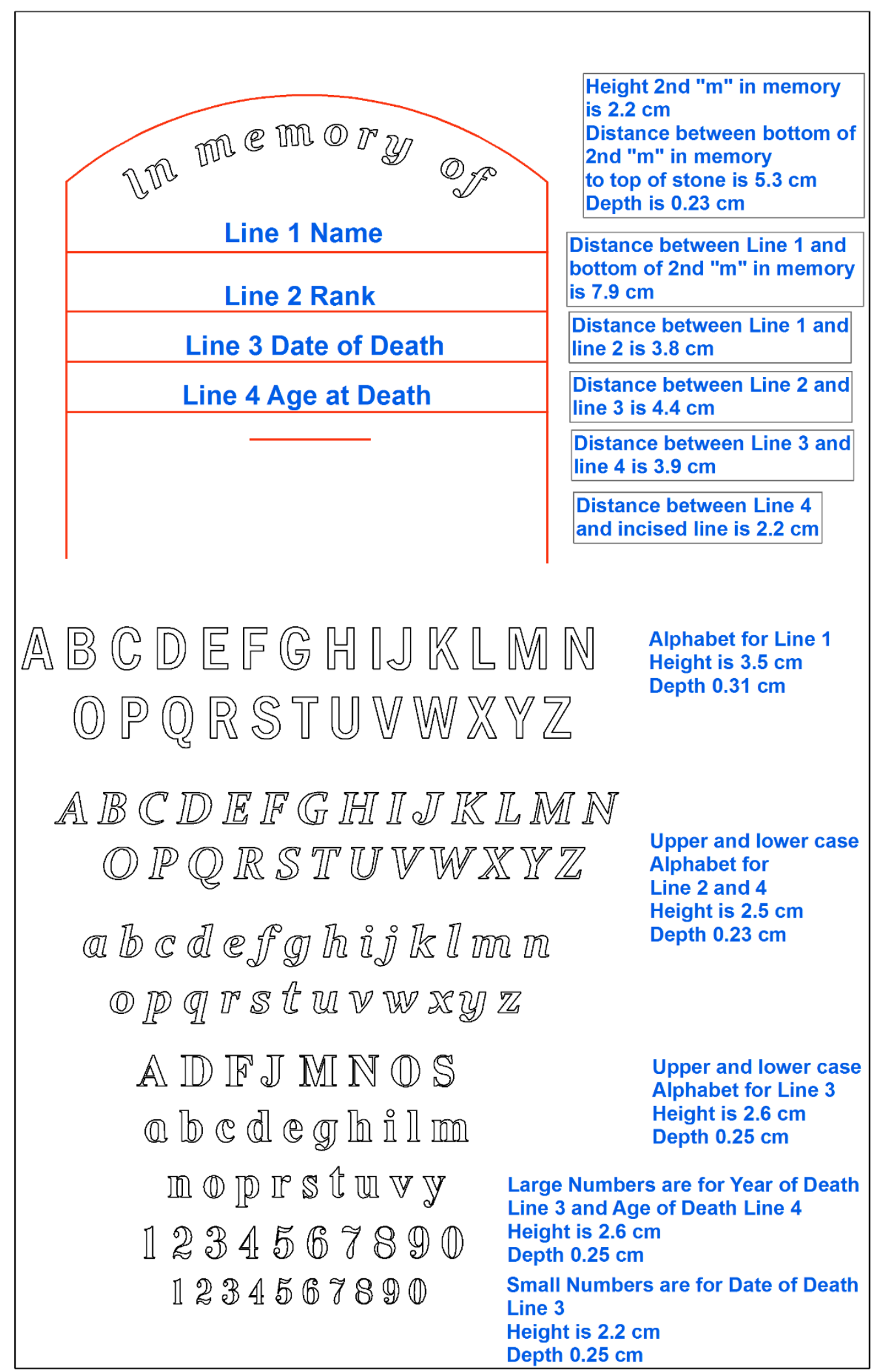


Figure 20. Type 3 variation 2 headstone (ERDC-CERL, 2017).

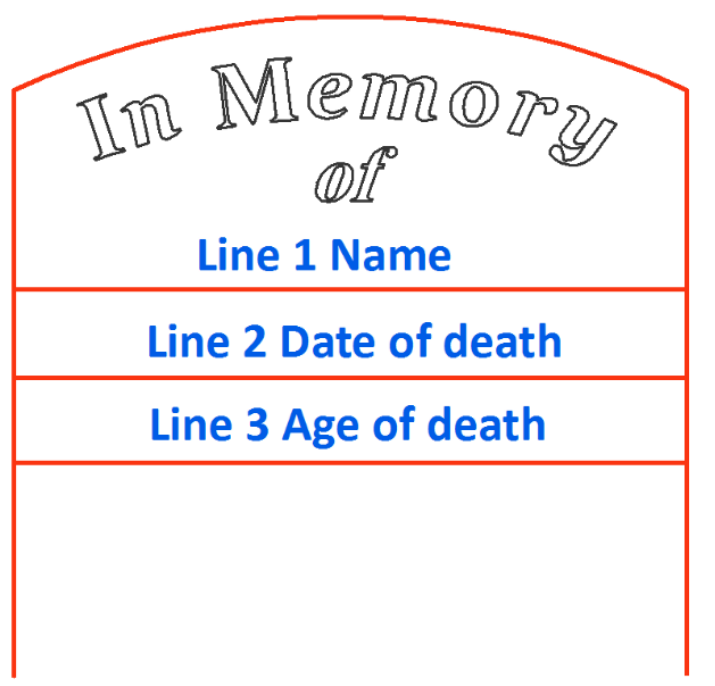

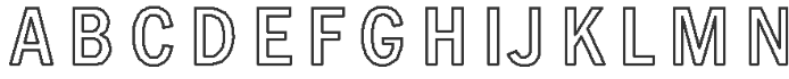
OPQRSTUVWYZ

$\mathbb{A} \mathbb{D} \mathbb{I} \mathbb{M} \mathbb{N} \mathbb{O S}$

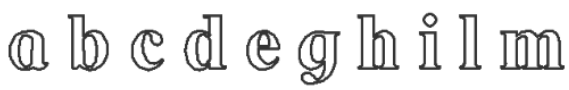

网 (1) [

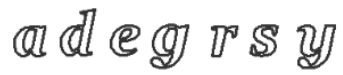

П2B 456789

$12 B 456780$
Distance from bottom of In Memory to top of stone at center line is $5.6 \mathrm{~cm}$ Distance from bottom of "of" to top of stone is $10.3 \mathrm{~cm}$ Height of "In Memory" and

"of" is $3.0 \mathrm{~cm}$ - depth of $0.24 \mathrm{~cm}$

Distance from Line 1 to bottom of "of" is $5.0 \mathrm{~cm}$ Distance from Line 1 to Line 2 is $5.0 \mathrm{~cm}$ Distance from Line 2 to Line 3 is $4.8 \mathrm{~cm}$

Alphabet for Line 1

Height $3.2 \mathrm{~cm}$

Depth $0.30 \mathrm{~cm}$

Alphabet for Line 2

Height $3.0 \mathrm{~cm}$

Depth $0.26 \mathrm{~cm}$

Alphabet for Line 3

Height $2.6 \mathrm{~cm}$

Depth $0.26 \mathrm{~cm}$

Large numbers are Year on Line 2 Height $3.0 \mathrm{~cm}$

Depth $0.26 \mathrm{~cm}$

Small numbers are for Day on Line 2 and age on line 3 Height $2.6 \mathrm{~cm}$ Depth $0.26 \mathrm{~cm}$ 
Figure 21. Type 4 headstone (ERDC-CERL, 2017).

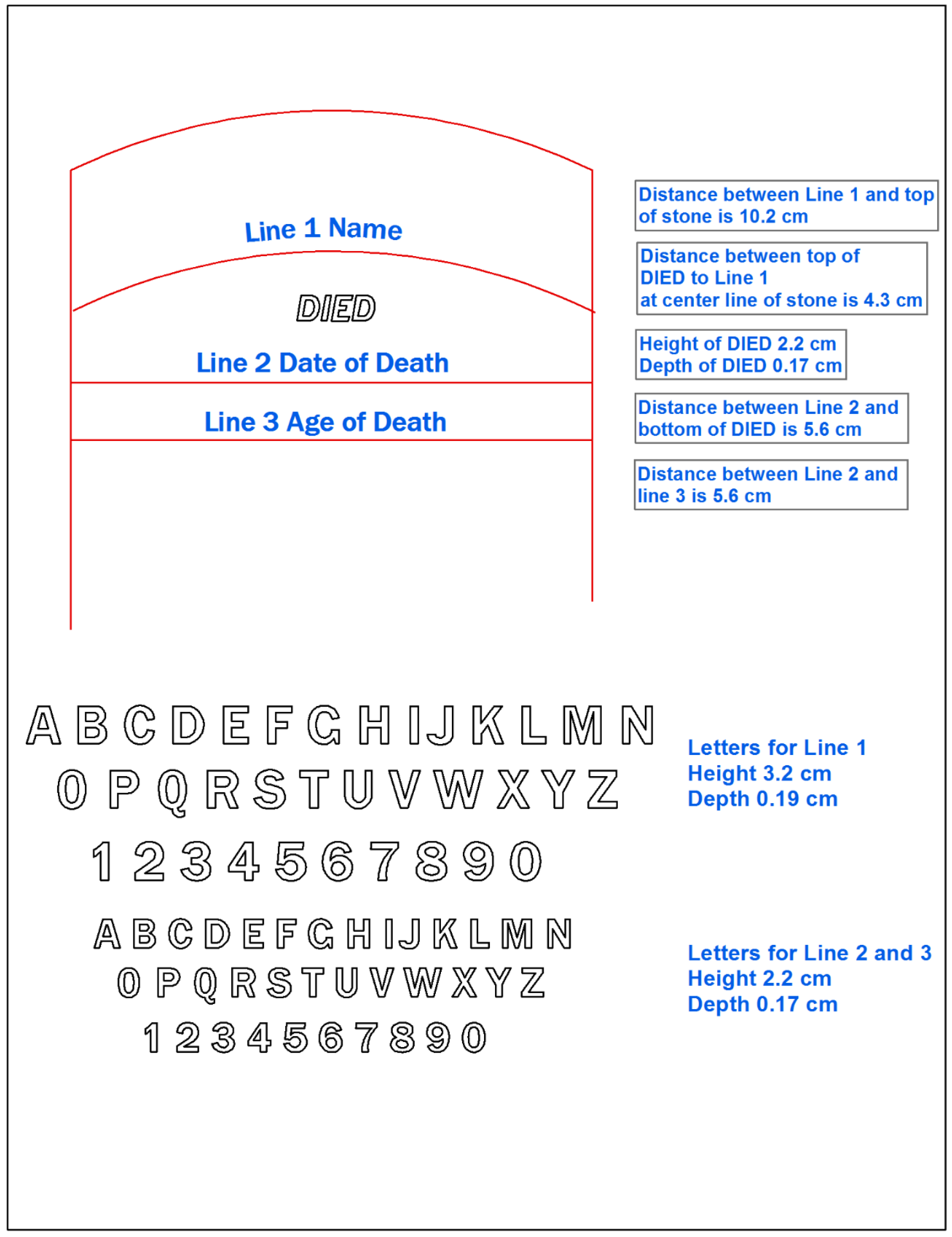


Figure 22. Type 5 variation 1 headstone (ERDC-CERL, 2017).

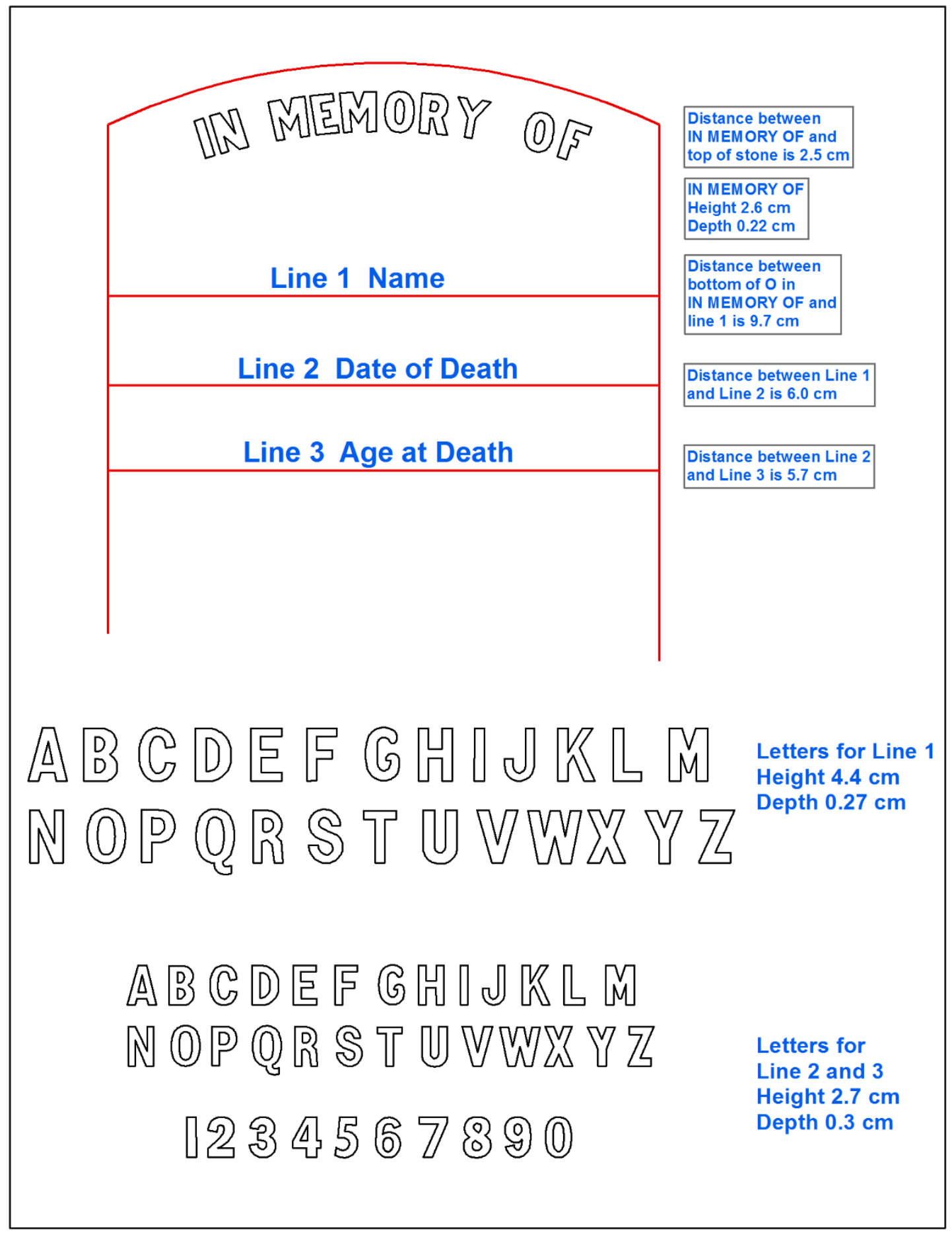


Figure 23. Type 5 variation 2 headstone (ERDC-CERL, 2017).

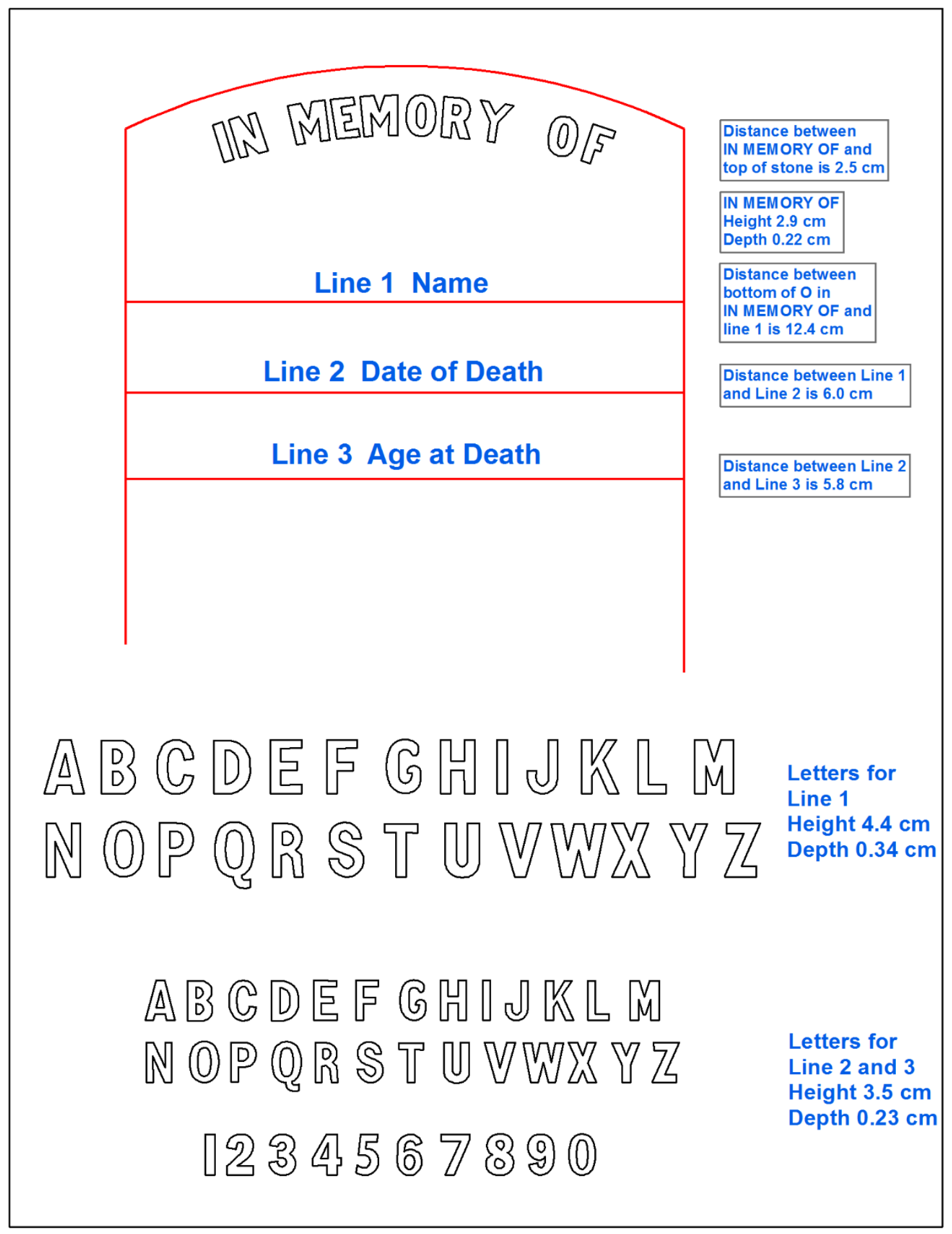




\section{Bibliography}

Bixler, Michael. 22 September 2017. "Mount Moriah Now Under New Management." Hidden City, PA: Hidden City Daily. https://hiddencityphila.org/2014/09/mt-moriahnow-under-new-management/.

“Corrections.”. November 22, 2005. Philadelphia, PA: Philadelphia Inquirer.

National Park Service. 2017. "Mount Moriah Cemetery Naval Plot and Soldier's Lot Philadelphia, Pennsylvania." Washington, DC: U.S. Department of the Interior, National Park Service.

https://www.nps.gov/nr/travel/national_cemeteries/pennsylvania/mount_moriah_cemetery_n aval_plot_and_soldiers_lot.html

Pompilo, Natalie. July 15, 2011. "Abandoned Mount Moriah in grave condition.” Philadelphia Inquirer. Retrieved January 21, 2013.

Preservation Alliance for Greater Philadelphia. 2015. "Mount Moriah Cemetery Gatehouse.” http://www.preservationalliance.com/place-to-save/mount-moriah/

Scharf, John Thomas, and Thompson Westcott. 1884. History of Philadelphia, 16091884. Philadelphia, PA: L.H. Everts \& Co. 


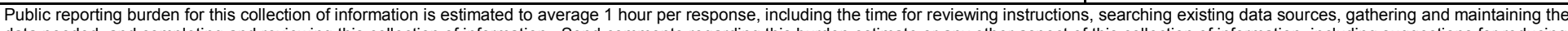

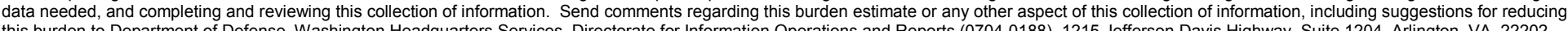

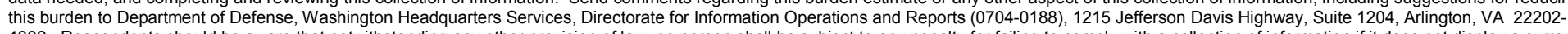

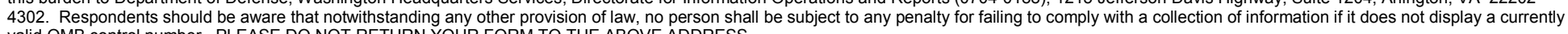
valid OMB control number. PLEASE DO NOT RETURN YOUR FORM TO THE ABOVE ADDRESS.
1. REPORT DATE (DD-MM-YYYY)
November 2017

\section{TITLE AND SUBTITLE}
2. REPORT TYPE
Final
5a. CONTRACT NUMBER

3-D Scanning of Headstones at the U.S. Naval Plot, Mount Moriah Cemetery, Philadelphia, PA

\section{AUTHOR(S)}

Carey L. Baxter, Andrew M. Hamblin, and Susan I. Enscore

\section{DATES COVERED (From - To)}

5b. GRANT NUMBER

5c. PROGRAM ELEMENT NUMBER

5d. PROJECT NUMBER

467132

5e. TASK NUMBER

5f. WORK UNIT NUMBER

8. PERFORMING ORGANIZATION REPORT NUMBER

U.S. Army Engineer Research and Development Center (ERDC)

Construction Engineering Research Laboratory (CERL)

PO Box 9005

Champaign, IL 61826-9005

\section{SPONSORING / MONITORING AGENCY NAME(S) AND ADDRESS(ES)}

U.S. Department of Veterans Affairs

National Cemetery Administration

Washington, DC 20420

\section{DISTRIBUTION / AVAILABILITY STATEMENT}

Approved for public release. Distribution is unlimited.

\section{SUPPLEMENTARY NOTES}

\section{ABSTRACT}

The site of this study was Mount Moriah Cemetery, a historic cemetery in Philadelphia, PA. Several historical types of headstones dating from the middle of the 19th through the middle of the 20th century were imaged with a Leica P40 laser scanner. The objective of this study was to use three-dimensional laser imagining to collect specifics of lettering fonts and placement for appropriate replication. At least three scanning stations were used for each headstone. A total of 67 scans were taken. Lettering was traced and provided in digital format. These letters were further processed in AutoCAD. Three-dimensional imaging provided useful information that can be modeled and replicated for reconstruction of headstones.

\section{SUBJECT TERMS}

Historic preservation, Cultural property_-Protection, National cemeteries--United States, Sepulchral monuments, Scanning systems, Landscape protection

16. SECURITY CLASSIFICATION OF:

a. REPORT

Unclassified

\section{b. ABSTRACT} Unclassified c. THIS PAGE

Unclassified

\section{LIMITATION} OF ABSTRACT

UU
18. NUMBER OF PAGES

34 19a. NAME OF RESPONSIBLE PERSON

19b. TELEPHONE NUMBER (include area code) 